\title{
Attitudes, knowledge, and opinions regarding mental health among undergraduate nursing students
}

\author{
ATITUDES, CONHECIMENTO E OPINIÃO FRENTE À SAÚDE MENTAL EM ALUNOS DE \\ GRADUAÇÃO EM ENFERMAGEM
}

\author{
ACTITUDES, CONOCIMIENTO Y OPINIÓN FRENTE A LA SALUD MENTAL EN \\ ESTUDIANTES DE PREGRADO EN ENFERMERÍA
}

\section{Sônia da Silva Santos ${ }^{1}$, Marcos Hirata Soares², Andréia Gonçalves Pestana Hirata ${ }^{3}$}

\begin{abstract}
A cross-sectional study involving 235 subjects was conducted in 2011 to compare the opinions of nursing students regarding mental illness and related care practices at two institutions in the state of Paraná, Brazil. Following approval by the ethics committee, data collection was initiated using an instrument containing questions regarding the importance of personal characteristics, knowledge of mental health, and the Opinions about Mental IIIness (OMI) scale. Statistical analyses, including the Mann-Whitney test, Chi-squared test, and Spearman correlation at $\alpha<0.05$, were performed using SPSSv. 15 . The students exhibited significantly different characteristics only for Benevolence. Regarding the importance of knowledge about mental health, in comparison with students from the State University of Londrina (Universidade Estadual de Londrina - UEL), students at the State University of Maringa (Universidade Estadual de Maringá - UEM) considered psychological aspects more comprehensively than technical knowledge $(p<0.01)$. We conclude that there are differences between students at these institutions in terms of knowledge and the factor Benevolence. Further studies are necessary to identify the underlying causes of such differences.
\end{abstract}

\section{DESCRIPTORS}

Students, nursing

Education, nursing

Mental disorders

Psychiatric nursing

Mental health

Nursing education research

\section{RESUMO}

Estudo transversal cujo objetivo foi comparar a opinião de estudantes de Enfermagem de duas instituições paranaenses frente à doença mental e suas práticas de cuidado. A coleta de dados foi realizada em 2011 com 235 sujeitos após aprovação do comitê de ética em pesquisa. Utilizou-se escala de Opiniões sobre a Doença Mental (ODM) e um instrumento composto de questões sobre a importância de características pessoais e conhecimento em saúde mental. A análise foi realizada por meio do programa estatístico SPSS-v.15, com os testes de Mann-Whitney e Qui-quadrado e a correlação de Spearman $(\alpha<0,05)$. Na ODM, os estudantes apresentaram características distintas, significativas apenas em relação à benevolência. Quanto à importância dos conhecimentos em saúde mental, os estudantes da UEM consideram de forma mais integral os aspectos psicológicos que os da UEL $(p<0,01)$. Concluiu-se que há diferenças entre os estudantes das instituições envolvidas em relação ao fator benevolência da ODM e ao conhecimento em saúde mental. Há necessidade de outros estudos que possam identificar com mais profundidade as causas dessas diferenças.

\section{DESCRITORES}

Estudantes de enfermagem

Educação em enfermagem

Transtornos mentais

Saúde mental

Pesquisas em educação de enfermagem

\section{RESUMEN}

Estudio transversal cuyo objetivo fue comparar la opinión de los estudiantes de Enfermería de dos instituciones de Paraná, Brasil, sobre la enfermedad mental y sus prácticas de cuidado. La recolección de datos se llevó a cabo en el 2011, con 235 sujetos después de la aprobación del comité de ética en investigación. Se utilizó la escala de Opiniones sobre Enfermedades Mentales (ODM) y un instrumento con preguntas sobre la importancia de las características personales y los conocimientos en salud mental. El análisis se realizó con el programa estadístico SPSSv.15, con las pruebas de Mann-Whitney y de Chi-cuadrado y la correlación de Spearman $(\alpha<0,05)$. En la ODM, los estudiantes presentaron diferentes características, significativas sólo en relación a la benevolencia. En relación a la importancia de los conocimientos en salud mental, los estudiantes de la UEM consideran más integralmente los aspectos psicológicos que los estudiantes de la UEL $(p<0,01)$. Se concluye que existen diferencias entre los estudiantes de las instituciones participantes en relación con la benevolencia de la ODM y los conocimientos en salud mental. Existe la necesidad de realizar otros estudios para identificar con mayor profundidad las causas de estas diferencias.

\section{DESCRIPTORES}

Estudiantes de enfermería

Educación en enfermería

Trastornos mentales

Enfermería psiquiátrica

Salud mental

Investigación en educación de enfermería

${ }^{1}$ Nurse for the Municipal Prefecture of Florestópolis-PR. soniasantossilva@yahoo.com.br ${ }^{2}$ Nurse and Assistant Professor of Psychiatric Nursing and Mental Health at theHealth Sciences Center, Nursing Department-UEL. Masters in Psychiatric Nursing from EERP_USP. Doctoral Candidate in the Graduate Program in Psychiatric Nursing-EERP/USP. mhirata@uel.br. ${ }^{3}$ Collaborate Professor in theNursing Department at the Health Sciences Center of theState University of Londrina (Universidade Estadual de Londrina - UEL) - Londrina (PR), Brazil. Student in the Graduate Program in Nursing at the State University of Maringa (Universidade Estadual de Maringá-UEM). andpest@hotmail.com 


\section{INTRODUCTION}

Psychiatric reform is defined by a historical process comprising a critique of the classical psychiatric model and the practices that seek to transform this model, which is called psychosocial healthcare ${ }^{(1)}$.

Although nursing is an important profession for articulating and consolidating the principles of psychiatric reform, this profession must invest in various strategies to change and revise the organic model that psychiatric nursing has adopted. Many considerations and aspects are thought to be necessary, including an improved workflow, better knowledge among nurses, the practice of interpersonal relations, and instruction ${ }^{(2)}$.

Dealing specifically with instruction, many researchers consider changes in mental health instruction necessary to improve the practice of nursing care. For example, certain researchers ${ }^{(3-4)}$ claim that a link between theory and practice is required so that future nurses can learn the aspects of encounters, the provision of care, rehabilitation, interpersonal relations, solidarity, acceptance, the introduction of novel subjectivities in the relationship between the phenomenon of mental health and society, and a focus on critiquing the role of this relationship.

Despite the difficulty of finding parameters for comparing the profiles of students/future nurses from different universities, conducting this study was important because it is believed that the concept of mental illness is a parameter for this comparison due to an independence from the curricular proposals. In other words, this concept is independent of the universities' proposed curricula as represented by the time required for the workload comprised of classes, internships, projects. Future nurses should exhibit a favorable attitude toward persons with mental disorders, according to the principles of Brazilian psychiatric reform ${ }^{(1)}$.Several international studies have used the same scale as this study to assess the efficacy of their educational programs and to compare the results for both academic and professional training ${ }^{(5-6)}$.

Other authors ${ }^{(7)}$ suggest that in addition to recounting the required changes, it is necessary to observe how such changes are effected in institutions and whether the goal is being achieved. Thus, we recognized the necessity to compare the concept of mental illness and care practices among undergraduate nursing students at the State University of Londrina (Universidade Estadual de Londrina - UEL) and the State University of Maringa (Universidade Estadual de Maringá - UEM).

The curricular structure at UEM is based on the traditional series model ${ }^{(8)}$, whereas UEL has an integrated curriculum aimed at combining content into modules, based on critical-reflexive teaching that prioritizes active methods of constructing knowledge, among other aspects. One of the premises adopted by the integrated curriculum is the critical-reflexive learning method, in which pedagogical practice is considered a social practice. This method values the sociocultural and psychological characteristics of the students and considers autonomy and professional responsibility as being dependent upon a large capacity for student reflection ${ }^{(9)}$.

The organizers of the work that relates the entire process for constructing the integrated curriculum ${ }^{(9)}$ mention the importance of three principles: totality, which requires that the whole and the parts be analyzed simultaneously; interdisciplinarity, which considers the importance of interdisciplinary dialogue; and the relationship between theory and practice, which should occur simultaneously.

The suggestions from various studies in the field of instruction in mental health were adopted as the theoretical foundation, and the most recent, relevant investigations ${ }^{(10-11)}$, including international studies ${ }^{(12-14)}$, were selected. The domestic studies conducted a broad survey on the topic and considered the complexity of instruction in psychiatric nursing and mental health. Through their critiques and discussions, the authors concluded that effective compliance with the psychosocial model is critical, to the detriment of the biological model, because models influence the teaching methods, theoretical content, curricular organization, and ultimately the theoretical and practical discourse of teachers.

Thus, inappropriate content taught in undergraduate courses and theoreticalpractical activities in mental health clinics based on the psychiatric-ward model contribute to future nurses developing ambivalent or negative attitudes toward persons with mental health disorders ${ }^{(10-11)}$. Such situations indirectly lead to low-quality mental healthcare and could bias future nurses against selecting the field of mental health as their area of work, as has been revealed by international studies ${ }^{(12-13)}$.

\section{METHOD}

The present investigation was a cross-sectional and individualized study. Nursing students from the 1st to the 4th series at the above mentioned two public institutions in the northeastern part of the State of Parana participated as subjects. The research proposal was approved by the Research Ethics Committee of UEL (CAAE \#0055.0.268.093-11). Data were collected (in a classroom) from all students who agreed to participate in the study. Following the implementation of the scale, 
the teacher responsible for the class was contacted to notify him/her of the study being conducted. The inclusion criterion for the present study was being an undergraduate nursing student at one of the institutions. In the series that included instruction in mental health (the 2 ndand 3 rd series at UEM and the 1 st and 4 th series at UEL), the subjects were interviewed after concluding the series/module to assess the expected change.

\section{Data collection instrument}

An instrument consisting of the Opinions about Mental IIIness ${ }^{(15)}$ (OMI) scale, which has been validated for Brazil(16), was used. The OMI is an important data source for designing programs and improving disciplines that deal directly with mental illness and mental health patients. The goal of this questionnaire is to study opinions regarding mental illness, and it contains 51 Likert items grouped into seven factors:

- Authoritarianism (factor A): This factor reflects the perspective that a person suffering psychologically must be isolated from other patients and remain behind barred doors under surveillance. It encompasses both the concept of the patients' personal and social irrecoverability and the idea that these patients are dangerous.

- Benevolence (factor B): This factor reflects the view that the person suffering psychologically, due to their misfortune, should be the subject of a kind and paternalistic protectionism based on care, personal attention, and material comfort.

- Ideology of mental hygiene (factor C): This factor represents the idea that the person suffering psychologically is similar to normal people, but with quantitative rather than qualitative differences. These individuals can perform specialized activities, including childcare.

- Social restriction (factor D): This factor represents the mental disorder as a type of hereditary defect that is completely distinct from other disorders or illnesses and suggests that the patients can transmit their disorder to their family and society. Therefore, these patients should be protected by restricting their personal and social rights even after hospitalization.

- Interpersonal etiology (factor E): This factor explains mental disorders as originating from interpersonal experiences, with a strong emphasis on the interaction with parental figures.

- Mental effort etiology (factor F): This factor reflects the idea that the mental disorder originates from excessive cerebral effort from exaggerated intellectual labor, thinking too much, or having negative thoughts.

- Minority view (factor $G$ ): This factor reflects the idea that the person suffering psychologically can be easily recognized among a group of humans as different from those considered normal, especially by the person's external appearance.

The second part consisted of two questions on the perception of the students' knowledge and abilities in mental health. For these questions, each student was asked to classify each content area in the area of mental health by ranking each item with a score from 0 to 10 . Higher scores indicated that the student placed greater importance on that content for delivering quality care.

These themes were called interpersonal relations (and/or therapeutic communication), psychopathology, psychiatric reform (mental health policies, organization of mental health services, and history of psychiatry), and therapies (psychopharmacological drugs, psychotherapy methods). Self-awareness, self-esteem, and self-confidence were also self-assessed in terms of importance on a scale from 0 to 10 , where 0 meant not important and 10 meant extremely important for providing nursing care in the mental health field.

\section{Data analyses}

After applying the $\mathrm{OMI}$, the raw factor scores were transformed into the Sten system, which provides a standard comparison among the factors, ranging from 1 to 10 , (mean $[M]=5.5$; standard deviation $[S D]=0.5)^{(17)}$, suggesting that the expected answers are between values 5 and 6 . The data were transferred to the program Statistical Package for Social Sciences (SPSS), v.15. First, a normality test was performed to select between parametric tests for a normal distribution and non-parametric tests for a non-normal distribution. The level of significance was set at $\alpha<0.05$. The data were analyzed using the Mann-Whitney test, the Chi-squared test $\left(X^{2}\right)$, and the Spearman correlation.

The Mann-Whitney and Chi-squared tests were used to compare two groups, that is, to compare the answers for factors on the OMI scale given by students at UEL and UEM. Thus, there was a comparison between the students from the different institutions, based on the hypothesis that the experience at a university and its respective teaching program are the explanatory factor for the presence or absence of differences between students who have the same major and similar socio demographic profiles, in terms of their attitude toward mental illness as measured by the OMI scale ${ }^{(18-23)}$.

The Spearman correlation seeks a linear relationship between two ordinal variables and can reveal whether there is a positive relationship (in which one variable increases with the other) or a negative relationship (in which one variable increases as the other decreases).

Thus, the correlation expresses the intensity of the relationship between two variables, and greater correlation coefficients, which range from -1 to +1 , reflect a 
greater intensity of such a relationship. Although there is no single way to interpret correlation values, for the present study, values between 0.40 and 0.60 were considered a moderate correlation; values of 0.60 to 0.80 were considered a strong correlation; and values of 0.80 to 1.0 were considered an extremely strong correlation ${ }^{(24)}$.

\section{RESULTS}

A total of 235 students participated in the present study, including $153(65.1 \%)$ students from UEL, which is equal to $63.75 \%$ of all students in the major at that institution, and 82 (34.9\%) students from UEM, or $51.25 \%$ of all students at that university. In total, 68 students (28.9\%) were in the $1^{\text {st }}$ year, 58 students $(24.7 \%)$ were in the 2 nd year, 63 students $(26.8 \%)$ were in the 3 rd year, and 46 students $(19.6 \%)$ were in the 4 th year. The majority of the subjects were female:214 (91.1\%) females versus 21 (8.9\%) males. In terms of age, 126(53.6\%) subjects were between 16 and 20 years of age, $96(40.9 \%)$ were 21 to 26 years of age, 11(4.7\%) were 26 to 30 years of age, and two(0.9\%) were 30 to 40 years of age. Tables 1 to 4 list the results of statistical tests performed to compare students from both universities participating in the study; the numbers denote the results of the comparisons made by the teste.

Table 1 - Comparison between undergraduate nursing students (UEL/UEM) regarding the importance of the themes of mental health and personal characteristics for the quality of nursing care, Londrina-Maringa, 2011.

\begin{tabular}{lccccccc}
\hline & Relations & Psychopathology & Reform & Therapy & Self-awareness & Self-esteem & Self-confidence \\
\hline Mann-Whitney U & 4014,000 & 4710,000 & 3465,500 & 4758,000 & 5131,500 & 5297,500 & 4852,500 \\
p-value &, 000 &, 001 &, 000 &, 002 &, 015 &, 039 &, 002 \\
\hline
\end{tabular}

Table 2 - Comparison of opinions about mental illness between undergraduate nursing students (UEL/UEM), regarding the factor Benevolence, Londrina-Maringa, 2011.

\begin{tabular}{lll}
\hline Factor/Test & \multicolumn{1}{c}{ U de Mann-Whitney } & p valor \\
\hline Benevolence & 5333,500 & 0,053 \\
& $\mathbf{X}^{2}$ Test with Yates Correction & 0.041 \\
\hline
\end{tabular}

Table 3 - Spearman correlation**(r) matrix for the scores given by students to the themes and personal characteristics in mental health at UEL-Londrina and UEM-Maringa, 2011.

\begin{tabular}{|c|c|c|c|c|c|c|c|}
\hline & Relations & Psychopathology & Reform & Therapy & Self-awareness & Self-esteem & Self-confidence \\
\hline Relations -UEM & \multirow{2}{*}{1} & - & - & - & - & - & - \\
\hline Relations -UEL & & - & - & - & - & - & - \\
\hline Psychopathology -UEM & 0,78 & \multirow{2}{*}{1} & - & - & - & - & - \\
\hline Psychopathology -UEL & 0,54 & & - & - & - & - & - \\
\hline Reform-UEM & 0,79 & 0,74 & \multirow{2}{*}{1} & - & - & - & - \\
\hline Reform-UEL & 0,47 & 0,60 & & - & - & - & - \\
\hline Therapy -UEM & 0,81 & 0,86 & 0,71 & \multirow{2}{*}{1} & - & - & - \\
\hline Therapy -UEL & 0,38 & 0,72 & 0,53 & & & - & - \\
\hline Self-awareness-UEM & 0,79 & 0,78 & 0,67 & 0,86 & \multirow{2}{*}{1} & - & - \\
\hline Self-awareness -UEL & 0,51 & 0,43 & 0,30 & 0,42 & & - & - \\
\hline Self-esteem -UEM & 0,76 & 0,84 & 0,72 & 0,89 & 0,85 & \multirow{2}{*}{1} & - \\
\hline Self-esteem -UEL & 0,34 & 0,32 & 0,32 & 0,25 & 0,66 & & - \\
\hline Self-confidence -UEM & 0,71 & 0,79 & 0,63 & 0,83 & 0,81 & 0,92 & \multirow{2}{*}{1} \\
\hline Self-confidence -UEL & 0,39 & 0,36 & 0,37 & 0,32 & 0,70 & 0,82 & \\
\hline
\end{tabular}

**The correlation is significant at the level $p<0.01$ (bilateral). 
Table 4 - The frequency, percentage, mean (M), and standard deviation (SD) for factor scores on the OMI scale from students (UEL/ UEM), Londrina-Maringa, PR, 2011.

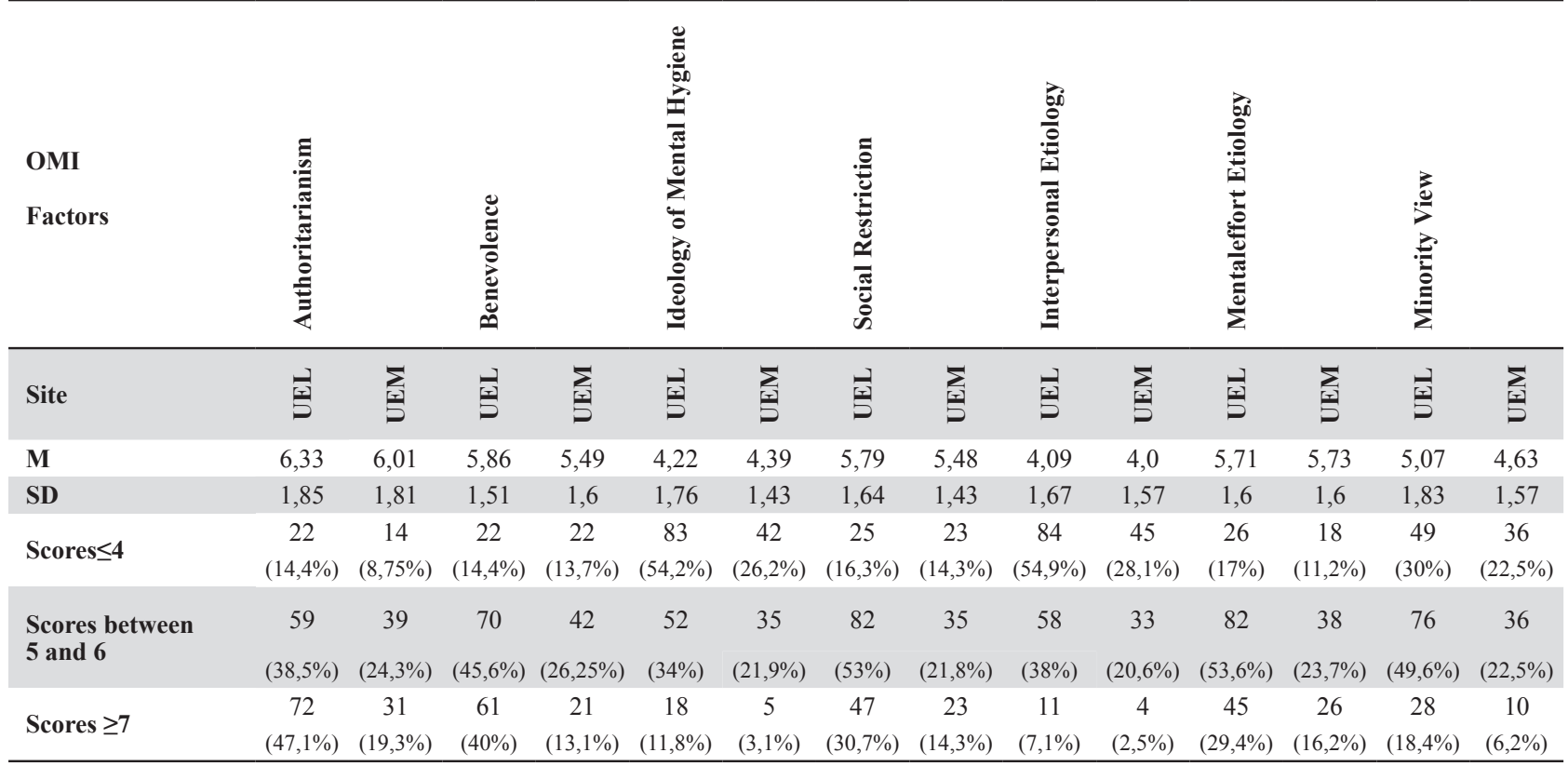

\section{DISCUSSION}

The normality test (Kolmogorov-Smirnov and Shapiro-Wilk with the Lilliefors correction) indicated that both samples had a non-normal distribution for the OMI scale factors, with a minimum $p=0.000$ and a maximum $p=0.026$, both at $p<0.05$. Therefore, we opted for the nonparametric Mann-Whitney test to determine whether there were significant differences in the responses given by students from UEL and UEM. The Chi-squared test was used to test for an association between the categorical variables. The Spearman correlation was used to determine the degree of correlation between the scores given for each theme in mental health.

As presented in Table 1, the Mann-Whitney test revealed a significant difference between the responses given by students from UEL and UEM. That is, students from UEL and UEM used the scores to rate each of the themes in mental health differently $(p<0.05)$. Such differences are believed to be directly caused by their university education and indirectly caused by the different curricular programs, at least regarding the theoretical proposal, as it has been established that there are evident inconsistencies in the learning process, as identified in various studies on instruction and learning in mental health ${ }^{(4,10-11,18-19)}$.

Thus, we can state that the students at UEL and UEM differently perceive the degree of importance placed on the evaluated themes and on self-awareness, self-esteem, and self-confidence as important personal characteristics for providing nursing care in mental health.

Several authors agree with such an interpretation ${ }^{(10-11)}$ and stress that students should undergo a learning process with a broad view of the human dimension during their academic training (starting with their self-awareness) that will help them address their fears and anxiety because the entire process of caring for another person requires emotional stability for both the caregiver and the person being cared for. This point leads us to reflect on the necessity for teaching strategies that will enable the student to develop self-awareness and that go beyond the valuation of the technical aspects.

Table 2 indicates that there were no significant differences regarding the scale factors $(p>0.05)$. It is assumed that there could be a significant difference for factor $B$ (Benevolence) ( $p=0.053$ ) with a larger sample. This hypothesis is supported by the $\mathrm{X} 2$ withYate's correction, which revealed a correlation between factor $\mathrm{B}$ (Benevolence) and the university variable, suggesting that the university plays a role, assuming that various characteristics such as internship areas, teacher training, course loads, learning methods, curricular development, etc. (10-11), influence the perceivable differences in this factor $\left(X^{2}=4.778 ; p=0.041\right)$. This point can also be assumed because a study conducted to assess the contribution of clinical internships at mental health services in the city of Victoria, Australia with 703 students $^{(13)}$ who had completed mental health internships revealed that various factors are involved in forming a better positive understanding of mental health as an area of work for nursing. Factors such as the amount of time spent with the preceptor in the internship area, the greater time requirement (e.g., 8 hours), and the male gender were thought to contribute to a greater appreciation of mental health by the nurse.

Other authors ${ }^{(6,12-14)}$ consider the theoretical content and practical experience to be important factors for 
nursing undergraduates to develop more positive attitudes toward patients with mental disorders. This effect is most evident in a study that evaluated changes in the opinion about mental illness, regarding the factors Authoritarianism, Benevolence, and Social Restriction ${ }^{(6)}$.

Although the differences between students at UEL and UEM are not entirely clear, the statistical tests suggest that students from both universities gave different responses for the factor Benevolence, and by revisiting the discussion on the theoretical foundation of instruction and learning in mental health ${ }^{(10-11)}$, we can develop the hypothesis that the differences indicated by the tests are linked to the teaching-learning process or even to sociodemographic differences ${ }^{(25)}$.

Therefore, based on this line of reasoning, it is likely that the integrated curriculum is contributing to significant but barely noticeable changes in the factor Benevolence. According to Table 4, the percentage of students with a mean between 5 and 6 is greater at UEL (45.6\% of the entire major) than at UEM $(26.25 \%$ of the entire major). This finding suggests that students at UEL were considered more benevolent toward the person suffering psychologically and believed that, due to the mental patients' misfortune, these individuals should be assisted through a kind and paternalist protectionism based on care, personal attention, and material comfort ${ }^{(15-16)}$. This interpretation is supported by a study that compared students between three countries ${ }^{(20)}$.

Various observations have been made in studies conducted by researchers on this topic ${ }^{(20-23)}$. For example, better attitudes depend on the proximity between the teachers and the specialists in the field, concluding that contact between thesetwo groups promotes better responses, similar to specialized training in the field. With the exception of certain studies ${ }^{(5-6)}$, the other investigations ${ }^{(21-23)}$ that used the $\mathrm{OMI}$ scale only presented the Sten factors descriptively, even when comparing responses, thus making it difficult to compare the results with the findings of the present study, which addresses the Brazilian setting. Such difficulty makes it important to compare future investigationsvia deep statistical analyses and to perform international studies.

Even assuming that the university variable is implicit in that its academic structure, human and material resources, and teaching design are the major factors responsible for the change in attitude and knowledge of future professionals, it is not possible to state which variables within the university may be responsible for the differences found, or even whether the development of the integrated curriculum at UEL contributed to the differences in the perception of mental health when comparing students from both institutions on the OMI scale. However, the statistical tests used found significant differences between the two groups of students analyzed, which deserve further study.
Nevertheless, considering the broad survey conducted by several authors ${ }^{(10-11)}$ who thoroughly analyzed various other studies despite the introduction of new proposals for instruction, it is necessary to review and assess the methods and strategies for learning used in the mental health field so that these approaches may change the professional profile of future nurses, as the developers of the integrated curriculum anticipated that such a curriculum would be better than the serial curriculum ${ }^{(7)}$.

An Australian university also has experience with the integrated curriculum and learning through skills ${ }^{(21-22)}$ approaches that are used at UEL. In that study, the authors considered instruction by the integrated curriculum model and learning through skills/abilities to be more appropriate for constructing more positive attitudes from future nurses toward patients with mental disorders.

One factor that appears highly consistent relates to the hourly workload ${ }^{(6,14)}$ and experience in non-asylum services ${ }^{(10-11,14)}$, which support empirical knowledge in the academic setting, as in psychiatric reform. One study that compared the profile of freshmen and graduates ${ }^{(22)}$ suggested that freshmen exhibit a more authoritarian, restrictive, and discriminatory nature relative to graduates, allowing for the interpretation that academic teaching drives significant changes in the student profile ${ }^{(18-20)}$.

One researcher who conducted various studies of the OMI scale ${ }^{(20-23)}$ believes that the profile of attitudes toward patients with mental disorders should become more consistent with a therapeutic attitude, starting with academic instruction, especially if students receive proper and efficient training. The profile of understanding found gives future nurses more effective behaviors during patient care, thus promoting advances in public policies on mental health.

This effect is represented by a study ${ }^{(5)}$ of 361 diverse employees and 239 medical students in Greece. The psychiatry professionals had more positive attitudes than the nurses did toward mental health patients. The authors concluded that training and contact with mental health patients are important issues for minimizing the stigma between mental health personnel and other professionals.

Thus, the considerations in these studies ${ }^{(16,20-23)}$ are supported, whereby teachers in the mental health disciplines within the nursing major play a crucial role in developing didactic strategies to train individuals who can perform actions apart from the classical model of psychiatry in the academics studied, when these actions are observed to be reproduced by the professionals providing care $e^{(5,26)}$.

According to Table 3, the correlations between the importance given to the themes and certain personal characteristics by the UEL students were generally smaller than the correlations revealed by the same test performed on the UEM students. For the UEL students, the minimum correlation (between biological therapies and self-esteem) 
was 0.251 and the maximum correlation (between self-confidence and self-esteem) was 0.823 . These results indicate that both themes are positively correlated. For the UEM students, the minimum correlation (between the psychiatric reform theme and self-awareness) was 0.676 and the maximum correlation (between self-esteem and self-confidence) was $0.928(p<0.01)$.

The greater the correlation, the greater the relationship was; in other words, the students placed greater importance on the listed themes and less importance when there was a smaller correlation. An interesting finding in the present study was that the correlations were greater for the responses given by the UEM students, which suggests that the UEM students have a more comprehensive view of mental health knowledge and care, given the greater strength of the correlations. Thus, the UEM students more comprehensively and broadly considered the various themes and certain personal characteristics as being important for good mental health care $(p<0.01)$.

Studies of the integrated curricular structure $\left({ }^{10-11,21-22,27-28}\right)$ suggest that the new model of learning and the transformations undergone by the curricular structure are the factors responsible for the students' improved attitudes toward patients with mental disorders. Thus, the hypothesis remains that the integrated curriculum may explain the differences found by the statistical tests performed on the students from the institutions analyzed.

Although a greater level of the factor Benevolence was found among the UEL students according to the themes analyzed, the UEM students had a more comprehensive view of mental health care, according to the Spearman correlation analysis presented in Table 3 . This result suggests a requirement to review the teaching process because comprehensiveness, which is one of the principles of the integrated curriculum, was apparently not fully developed ${ }^{(9)}$, as evidenced by the contradictory data.

The data in Table 3 suggest that the students had a concept of comprehensiveness in mental health care and understood that it is as important to have academic knowledge for providing good care as it is to consider their subjective, personal characteristics when providing mental health care, as has been demonstrated in other studies ${ }^{(4,7,10-11)}$. However, this conceptualization occurred at different levels in students at the two institutions; the UEM students had a more comprehensive view of mental health care and valued the scientific aspects as well as the psychological and personal aspects $(p<0.05)$.

\section{CONCLUSIONS}

The differences found for the factor Benevolence, as measured by the OMI scale and in view of the importance of various themes in mental health, cannot be clearly explained by the curricular structure or by another variable specific to the university. Therefore, the hypothesis remains to be further developed and tested, and it is necessary to study which causes explain these differences, as suggested by some investigations that indicate, for example, the hourly workload and the amount of close contact with patients.

In terms of the perception of important knowledge for mental health nursing care, the students valued both psychological aspects (such as self-confidence, self-awareness, and self-esteem) and specific technical knowledge (such as psychopathology, psychiatric reform, etc.), thereby indicating that the students conceptualize comprehensive mental health care. However, this view is broader and more comprehensive in the UEM students than in the UEL students.

The complexity of the teaching-learning process and other subjective characteristics that were not addressed are considered limitations of the present study. Although assessment of the teaching-learning process in mental health cannot be reduced to the application of a single psychometric instrument, the present study yielded significant results. Despite the involvement of learning institutions with different pedagogical programs, it is believed that the attitudes toward mental health should be as appropriate as possible considering the indirect role of these attitudes in the quality of psychiatric nursing care. Additionally, the learning methodology implemented for the nursing major at UEL should be reviewed.

\section{REFERENCES}

1. Kantorski LP, Silva GB. Ensino de enfermagem e reforma psiquiátrica. Pelotas: Ed. Universidade Federal de Pelotas; 2001.

2. Arvaniti A, Samakouri M, Kalamara E, Bochtsou V, Bikos C, Livaditis M. Health service staff's attitudes towards patients with mental illness. Soc Psychiatry Psychiatr Epidemiol. 2009;44(8):658-65.

3. Madianos MG, Priami M, Alevisopoulos G, Koukia E, Rogakou E. Nursing students' attitude change towards mental illness and psychiatric case recognition after a clerkship in psychiatry. Issues Ment Health Nurs. 2005;26(2):169-83.
4. Fernandes JD, Sadigursky D, Silva RMO, Amorim AB, Araújo MCF. Teaching psychiatric nursing/mental health: its interface with the Brazilian Psychiatric Reform and national curriculum guidelines. Rev Esc Enferm USP [Internet]. 2009 [cited 2012 June 06];43(4):962-8. Available from: http://www.scielo.br/ pdf/reeusp/v43n4/en_a31v43n4.pdf

5. Universidade Estadual de Maringá, Pró-Reitoria de Ensino (PEN). Cursos [Internet]. Maringá; 2006 [citado 2011 set. 17]. Disponível http://www.pen.uem.br/html/modules/tinyd0/index.php?id $=17 \&$ secao $=$ cursos 
6. Dellaroza MSG, Vannuchi MT, organizadoras. O Currículo Integrado do Curso de Enfermagem da Universidade Estadual de Londrina: do sonho a realidade. São Paulo: Hucitec; 2005.

7. Souza MCBM. O ensino de Enfermagem Psiquiátrica e/ou saúde mental: avanços, limites e desafios [tese livre-docência]. Ribeirão Preto: Escola de Enfermagem de Ribeirão Preto, Universidade de São Paulo; 2010.

8. Rodrigues J, Santos SMA, Spriccigo JS. Teaching nursing care in mental health in undergraduate nursing. Acta Paul Enferm [Internet]. 2012 [cited 2012 jun. 06];25(6):844-51. Available from: http://www.scielo.br/pdf/ape/v25n6/en_v25n6a04. pdf

9. Happell B, Robins A, Gough K. Developing more positive attitudes towards mental health nursing in undergraduate students: part 1- does more theory help? J Psychiatr Mental Health Nurs. 2008;15(6):439-46.

10. Gough K, Happell B. Undergraduate nursing students attitude to mental health nursing: a cluster analysis approach. J ClinNurs. 2009;18(22):3155-64.

11. Happell B, Robins A, Gough K. Developing more positive attitudes towards mental health nursing in undergraduate students: part 2 - the impact of theory and clinical experience. J Psychiatr Ment Health Nurs. 2008;15(7):849-85.

12. Cohen J, Struening EL. Opinions about mental illness: mental hospital occupational profiles and profiles clusters. Psychol Rep. 1963;12(1):111-24.

13. Rodrigues CRC. Atitudes frente à doença mental: estudo transversal de uma amostra de profissionais da saúde [tese doutorado]. Ribeirão Preto: Escola de Enfermagem de Ribeirão Preto, Universidade de São Paulo; 1983.

14. Canfiled AA. The "Sten" Scale-A Modified C-Scale. Educ Psychol Meas. 1951;11(2):295-7.

15. Camillo SO, Silva AL, Nascimento AJ. Perceptions of nursing undergraduate students concerning the human dimension in the learning process. Rev Latino Am Enferm. 2007;15(2):207-13.
16. Kantorski LP, Pinho LB, Saeki T, Souza MCBM. Expectativas de docentes sobre o ensino do cuidado em saúde mental. Rev Eletr Enferm [Internet]. 2006 [citado 2012 jun. 06];8(3):3639. Disponível em: http://www.fen.ufg.br/revista/revista8_3/ v8n3a07.htm

17. Pedrão LJ, Galera SA, Silva MC, Cazenave Gonzalez A, Costa Júnior $M L$, Souza $M C$, et al. Attitudes of graduate nursing students towards mental disorders in Brazil, Chile and Peru. Rev Latino Am Enferm. 2005;13(3):339-43.

18. Avanci RC, Malaguti SE, Pedrão LJ. Authoritarianism and benevolence towards mental illness: study with students beginning a nursing program. Rev Latino Am Enferm. 2002;10(4):509-15.

19. Pedrão LJ, Avanci RC, Malaguti SE, Aguilera AMS. Atitudes frente à doença mental: estudo comparativo entre ingressantes e formandos em enfermagem. Medicina (Ribeirão Preto). 2003;36(1):37-44.

20. Pedrão LJ, Avanci RC, Malaguti SE. Profile of undergraduate nursing students' attitudes as to mental disease before the influence of specific courses. Rev Latino Am Enferm. 2002;10(6):794-9.

21. Bisquerra R, Sarriera JC, Martínez F. Introdução à estatística. Porto Alegre: Artmed; 2004.

22. Eurich RB, Kluthcovsky AGC. Avaliação da qualidade de vida de acadêmicos de graduação em enfermagem do primeiro e quarto anos: influência das variáveis sociodemográficas. Rev Psiquiatr (Rio Gd Sul) 2008;30(3):211-20.

23. Tavares RR, Pedrão LJ. Análise comparativa da opinião de enfermeiros de diferentes unidades psiquiátricas sobre a pessoa em sofrimento psíquico. Cogitare Enferm. 2003;8(1):75-86.

24. Lecuyer E, Desocio J, Brody M, Schilick R, Menkens R. From objectives to competencies: operationalizing the NONPF PMHNP competencies for use in a graduate curriculum. Arch Psychiatr Nurs. 2009;23(3):185-99.

25. Happell B, Rushmorth L. Caneducational methods influence the pópularity of psychiatric nursing? Nurs Educ Today. 2000;20(4):318-26. 